\title{
NILAI SENSORI, pH DAN TVB PETIS DARI CAIRAN PEMINDANGAN IKAN LAYANG (Decapterrus sp.) YANG DIOLAH MENGGUNAKAN ASAM YANG BERBEDA
}

\author{
The Sensory Value, pH and TVB of Flying Fish (Decapterus spp.) Paste Treated Using Different Acids
}

\author{
Alfiyyah Nur Rahmah', Asnani', Sri Rejeki ${ }^{2}$ \\ 1Jurusan Teknologi Hasil Perikanan, Fakultas Perikanan dan IImu Kelautan Universitas Halu Oleo, Kendari, \\ Sulawesi Tenggara, Indonesia \\ 2Jurusan Ilmu dan Teknologi Pangan, Fakultas Pertanian Universitas Halu Oleo, Kendari, Sulawesi Tenggara, \\ Indonesia \\ *Email korespondensi: alfiyyahnurrahmah@gmail.com (Telp: +6282346517094) \\ Diterima: 15 Juli/ Disetujui 30 Oktober 2020
}

Cara sitasi: Rahmah AN, Asnani, Rejeki S. 2020. Nilai sensori, pH dan TVB petis dari cairan pemindangan ikan layang (Decapterrus sp.) yang diolah menggunakan asam yang berbeda. Jurnal Fish Protech. 3(2):200-206.

\begin{abstract}
Petis is a processed or preserved product that is included in a sauce group that resembles thick, clay and elastic pulp, black or brown in color depending on the type of material used and is a food product that has a semi-solid texture. A paste made from fish or shrimp broth that is cooked until thick. This study aims to determine the sensory properties, $\mathrm{pH}$ values and TVB values of flying fish paste by using three different types of acid. This study used a Completely Randomized Design (CRD) with three treatments, namely the use of different types of acids, namely lime, vinegar and starfruit, using concentrations $0.4 \%$. Based on the results of the test, showed that the different treatments significantly affected the sensory value taste. petis of lime has the highest mean value for the taste with content 3,79. $\mathrm{pH}$ values and TVB values content of petis of lime were 5,13 and 7,408 $\mathrm{mgN} / 100 \mathrm{~g}$.
\end{abstract}

Keywords: Petis, Flying Fish, TVB, pH

\section{ABSTRAK}

Petis merupakan kelompok pangan berbentuk pasta yang merupakan hasil samping dari pengolahan hasil perikanan yang terbuat dari kaldu ikan atau udang yang dimasak hingga pekat. Tujuan penelitian ini adalah untuk mengetahui sifat sensori, nilai pH dan nilai TVB petis dengan bahan utama cairan ikan layang pindang yang diolah menggunakan tiga jenis asam yang berbeda. Rancangan yang digunakan meliputi Rancangan Acak Lengkap (RAL) dengan perlakuan: jeruk nipis, asam cuka dan asam sunti masing-masing dengan konsentrasi yang sama $(0,4 \%)$. Berdasarkan hasil uji menunjukkan bahwa penggunaan jenis asam pada pembuatan petis ikan layang berpengaruh nyata terhadap nilai sensori rasa petis, dimana perlakuan petis dengan penambahan jeruk nipis memiliki nilai rerata tertinggi untuk atribut rasa yaitu 3,79 (suka). Nilai pH dan nilai TVB perlakuan petis jeruk nipis masing-masing sebesar 5,13 dan $7,41 \mathrm{mgN} / 100 \mathrm{~g}$.

Kata kunci: Petis, Ikan Layang, TVB, pH

\section{PENDAHULUAN}

Ikan layang (Decapterrus sp.) merupakan salah satu sumber daya ikan pelagis kecil yang memiliki potensi dan nilai ekonomis tinggi di Sulawesi Tenggara. Beberapa daerah penangkapan ikan layang di Sulawesi Tenggara adalah di Perairan Menui, Perairan Saponda, dan Perairan. Data Dinas Kelautan dan Perikanan Provinsi Sulawesi Tenggara dari tahun 2007- 2011, rata-rata $69.50 \%$ dari total produksi ikan 
layang di tiga Kabupaten/Kota (Kota Kendari, Kabupaten Konawe, dan Konawe Utara) didaratkan di PPS Kendari (PPS, 2011).

Ikan layang banyak diolah menjadi berbagai jenis makanan, salah satunya adalah pemindangan, yaitu menghasilkan produk ikan semi basah dengan rasa yang khas dan tidak terlalu asin (Winarno, 2002). Bahan yang sering digunakan dalam pemindangan adalah ikan layang (Purnomo, 2002) yang memiliki kandungan gizi cukup tinggi yaitu jumlah protein $27 \%$, lemak $3 \%$, energi 176 kalori, air $60 \%$, mineral $0,26 \%$, serta vitamin B $0,07 \mathrm{mg}$ (Heruwati, 1986). Proses pengolahan ikan pindang akan memberikan hasil samping berupa limbah, terutama limbah cair yang dihasilkan dari proses pencucian dan perebusan ikan dalam jumlah yang tidak sedikit. Gonzales dalam Oktavia dkk. (2012), bahwa air limbah hasil buangan industri pengolahan hasil laut mengandung berbagai macam bahan organik seperti sisa daging, isi perut, protein, lemak dan karbohidrat yang akan berpengaruh terhadap karakteristik air limbah tersebut.

Pemanfaatan limbah cair pengolahan ikan pidang diantaranya pembuatan pupuk. Waryanti dkk (2013), limbah ikan dapat dimanfaatkan sebagai bahan baku pupuk organik lengkap. mengandung banyak protein dan lemak, sehingga mengakibatkan nilai nitrat dan amonia yang cukup tinggi. Selain itu, dalam bidang pangan, limbah cair tersebut dapat dipekatkan atau dikentalkan dengan penambahan bahan bahan pembantu penyedap menghasilkan produk yang dinamakan petis. Menurut penelitian Cahya (2004) menyatakan bahwa petis air rebusan kepala ikan memiliki kadar air berkisar 20,9\%-25,2\%, protein $15,8 \%-22,2 \%$, lemak 7,9\%-12,9\%, abu 3,3\%-6,7\%, dan karbohidrat 39,3\%-45,8\%. Viskositas berkisar 197,5-525 cp. Nilai sensori untuk kenampakan, tekstur, bau, dan rasa berkisar 6-8.

Petis ikan yang dijumpai masih mengandung bau amis yang didapat dari sumber ikan itu sendiri. Cara yang umum digunakan untuk menghilangkan bau amis pada ikan adalah dengan memberikan perasan air jeruk nipis. Larutan tersebut efektif dalam menghilangkan bau amis pada ikan sebab mengandung senyawa asam sitrat dan asam askorbat yang dapat bereaksi dengan senyawa TMA membentuk senyawa trimetil ammonium yang selanjutnya diubah ke bentuk bimetal ammonium, hingga bau amis pada ikan hilang (Poernomo et al., 2004). Sulaiman (1982) menyatakan bahwa penggunaan asam cuka 10\% pada ikan mujair yang dipanggang dapat mengurangi bau amis ikan. Asam sunti dapat memberikan cita rasa, warna dan kekentalan pada masakan. Selain itu, Kandungan asam (6.08 gr/100 gr bahan) dan garam $(27,4 \%$ ) yang cukup tinggi pada asam sunti dapat menghambat proses pembusukan oleh mikroorganisme dan memberikan efek pengawetan pangan, khususnya pada ikan (Saptriyawati, 2010). Berdasarkan latar belakang diatas, maka dilakukan penelitian dengan tujuan untuk mengetahui mutu sesori, nilai TVB dan $\mathrm{pH}$ petis dari cairan ikan pindang yang diolah menggunakan tiga jenis asam yaitu jeruk nipis, asam sunti dan asam cuka.

\section{Alat dan Bahan}

\section{METODE PENELITIAN}

Alat yang digunakan pada penelitian ini terdiri dari dari alat untuk pengolahan dan alat analisis. Alat pengolahan meliputi timbangan digital, panci, kompor, gelas ukur. Sedangkan peralatan analisi meliputi: $\mathrm{pH}$ meter, timbangan analitik, oven, inkubator, pipet, gelas kimia, alumunium foil, plastik klip, geget, batang pengaduk, pinset dan mortal

Bahan-bahan yang digunakan dalam penelitian ini terdiri atas bahan untuk mengolah ikan pindang meliputi: ikan layang, jeruk nipis, asam cuka, asam sunti dan dan garam. Sedangkan bahan untuk mengolah petis meliputi gula aren, gula pasir, bawang putih, bawang merah, cabe rawit, air bersih, lada, tepung tapioka, garam. Adapun bahan utama untuk analisis kimia terdiri dari TCA, aquades, sampel, $\mathrm{H}_{3} \mathrm{PO}_{4}$ (asam boraks). 


\section{Prosedur Penelitian}

\section{Preparasi jenis asam}

Buah jeruk nipis dipotong menjadi beberapa bagian kemudian diperas dan disaring pada wadah gelas. Asam cuka dalam botol disiapkan/dipindahkan dalam wadah gelas.Adapun pembuatan asam sunti (Muzaifah, 2018) yaitu dengan cara menjemur $1 \mathrm{~kg}$ belimbing wuluh selama 2 hari hingga warnanya berubah menjadi kecoklatan $( \pm 70 \%$ berat belimbing wuluh awal). Selanjutnya dilakukan penggaraman tahap 1 (setiap tahap ditambahkan garam sebesar 4\% dari berat belimbing wuluh setelah penjemuran) kemudian dimasukkan kedalam wadah tertutup dan didiamkan pada tempat gelap semalaman (fermentasi spontan). Selanjutnya dilakukan penjemuran hingga beratnya mencapai $\pm 40 \%$ berat belimbing wuluh awal dan dilakukan penggaraman tahap 2. Tahap ini diulang hingga diperoleh produk dengan berat $16 \%$ dari belimbing wuluh awal (pada penelitian ini dilakuakn 3 tahap penggaraman). Belimbing wuluh yang telah kering direndam di dalam air bersih selama 30 menit kemudian diperas dan airnya disaring disimpan dalam wadah gelas.

\section{Pembuatan ikan pindang}

Bahan baku ikan disiangi, dan dibersihkan sisik dan isi perut. Dilakukan pencucian menggunakan air mengalir. Ikan sebanyak $1 \mathrm{~kg}$ setiap perlakuan disusun rapi dan teratur didalam wadah yang telah disediakan, diberi air perbandingan sebanyak $500 \mathrm{ml}$ setiap perlakuan. Proses pemindangan ikan layang selama 20 menit.

\section{Pembuatan petis ikan}

Pembuatan petis Ikan Layang dilakukan mengikuti Danitasari (2010) dimana cairan ikan pinang yang telah dibuat sebelumnya disaring dan diukur masing-masing perlakuan sebanyak $200 \mathrm{ml}$. Cairan ikan pindang yang telah diukur masing-masing ditambahkan dengan jenis asam yang berbeda (jeruk nipis, asam cuka, asam sunti) dengan konsentrasi $4 \%$. Selanjutnya bahan dilakukan pemanasan pada suhu $100^{\circ} \mathrm{C}$ selama 10 menit. Selanjutnya penambahan gula pasir dan gula aren masing-masing $2 \%$, aduk dan panaskan selama 5 menit, kemudian ditambahkan bawang putih goreng, bawang merah goreng dan cabai masing-masing sebesar $1 \%$ dan lada bubuk 0,5\%, selanjutnya dipanaskan selama 10 menit hingga mengental. Penambahan tepung tapioka sebanyak $2 \%$, selanjutnya bahan disaring dan dilakukan pendinginan.

\section{Rancangan Penelitian}

Rancangan penelitian yang digunakan adalah Rancangan Acak Lengkap (RAL) dengan 3 taraf perlakuan yaitu dengan penambahan jeruk nipis $0,4 \%$, asam cuka $0,4 \%$ dan asam sunti $0,4 \%$, dengan tiga kali ulangan sehingga diperoleh 9 (sembilan) satuan percobaan.

\section{Parameter Uji}

Uji sensori dilakukan berdasarkan uji hedonik menggunakan 30 orang panelis. Atribut sensori yang diuji berupa tingkat kesukaan terhadap aroma, warna, rasa, penampakan dan tekstur. Perlakuan terbaik dari uji indeks efektifitas selanjutnya dilakukan pengujian $\mathrm{pH}$ dan TVB dari sampel terpilih.

\section{Analisis Data}

Data hasil penelitian organoleptik dianalisis menggunakan sidik ragam ANOVA (Analisis of Varians), jika terdapat perbedaan yang signipikan maka akan dilakukan dengan uji Duncan pada tingkat kepercayaan 95\% ( $a=0,05)$. 


\section{Pengujian Hedonik}

\section{HASIL DAN PEMBAHASAN}

Nilai rerata hedonik warna, aroma, kenampakan, tekstur dan rasa produk petis ikan layang dengan penambahan jenis asam yang berbeda terhadap penilaian uji sensorik disajikan pada Tabel 1.

Tabel 1. Nilai rata-rata uji hedonik petis dari cairan pindang ikan layang

\begin{tabular}{cccccc}
\hline Jenis asam (0,4\%) & Warna & Aroma & Kenampakan & Tekstur & Rasa \\
\hline Jeruk nipis & 3,84 & 3,97 & 3,87 & 3,68 & 3,79 \\
Asam cuka & 3,65 & 3,81 & 3,28 & 3,79 & 3,47 \\
Asam sunti & 3,70 & 3,72 & 3,53 & 3,50 & 3,40 \\
\hline Keterangan: warna (4 = suka); aroma (4 = suka); kenampakan (3 = agak suka; $4=$ suka); tekstur (4 = suka) \\
\multicolumn{4}{c}{ dan rasa (3 = agak suka.; $4=$ suka). }
\end{tabular}

Berdasarkan hasil analisis sidik ragam ANOVA menunjukkan bahwa penambahan jenis asam yang berbeda pada petis ikan layang berpengaruh signifikan terhadap pengujian hedonik atribut rasa, sedangkan pada atribut penilaian sensori yang lain berpengaruh tidak nyata. Hasil uji lanjut DMRT rasa dapat dilihat pada Tabel 2.

Tabel 2. Hasil uji hedonik terhadap atribut rasa petis dengan penambahan asam yang berbeda

\begin{tabular}{ccc}
\hline Jenis asam $(0,4 \%)$ & Rata-rata $\pm S D$ & DMRT $_{0,05}$ \\
\hline Jeruk nipis & $3,79^{\mathrm{a}} \pm 0,11$ & 3,39 \\
Asam cuka & $3,47^{\mathrm{a}} \pm 0,12$ & 3,47 \\
Asam sunti & $3,40^{\mathrm{b}} \pm 0,12$ & 3,79 \\
\hline
\end{tabular}

\section{Warna}

Berdasarkan hasil penelitian untuk pengujian hedonik atribut warna (Tabel 1) menunjukkan bahwa nilai rata-rata penilaian berkisar antara 3,65-3,84 (suka). Nilai hedonik warna petis dengan penambahan jeruk nipis lebih disukai karena warna asli dari jeruk nipis yang bening agak keputihan tidak terlalu mempengaruhi warna produk akhir, petis dengan penambahan asam sunti memiliki nilai yang lebih rendah dikarenakan asam sunti yang digunakan memiliki warna hitam kecoklatan yang mempengaruhi warna petis menjadi lebih gelap. Winarno (1997) juga menambahkan bahwa reaksi pencoklatan selama pengolahan juga dapat mempengaruhi warna produk. Manat dan Wirawan (2012) menyatakan bahwa reaksi pencoklatan pada produk petis mempengaruhi tingkat penerimaan petis ikan, dimana petis dengan warna kuning muda kecoklatan dianggap diinginkan.

\section{Aroma}

Berdasarkan (Tabel 1), nilai rata-rata aroma petis ikan layang berkisar antara 3,72-3,97 (suka). Nilai rerata tertinggi yaitu pada produk petis perlakuan P1 dengan penambahan jeruk nipis dan nilai terendah pada perlakuan $\mathrm{P} 3$ yaitu petis dengan penambahan asam sunti. Aroma petis ikan layang sendiri dipengaruhi oleh perubahan senyawa TMAO menjadi TMA yang direduksi oleh mikroba pembusuk (Saleh et al., 1975). Hal ini juga sesuai dengan pernyataan (Rusmono, 1983 dalam Sopyan, 2012) tepung tapioka tidak mengubah aroma petis bandeng dan diperoleh aroma spesifik jenis pada petis bandeng. Menurut Sulaiman (1982) menyatakan bahwa penggunaan asam cuka $10 \%$ pada ikan mujair yang dipanggang dapat mengurangi bau amis ikan. Poernomo (2004) menambahkan bahwa penggunaan ekstrak jeruk nipis sebesar $15 \%$ cukup efektif dalam mengurangi bau amis petis ikan layang. Beberapa senyawa asam seperti asam sitrat dan asam askorbat dapat bereaksi dengan senyawa TMA membentuk senyawa trimetil ammonium yang selanjutnya diubah ke bentuk bimetal ammonium, hingga bau amis pada ikan hilang (Poernomo et al., 2004).

\section{Kenampakan}

Berdasarkan hasil dari (Tabel 1) menunjukkan bahwa nilai hedonik kenampakan petis ikan layang berkisar antara 3,28-3,87 (agak suka-suka). Rendahnya nilai hedonik patis ikan layang dengan penambahan asam sunti dikarenakan kotoran halus dari jenis asam ini yang tidak ikut tersaring sehingga pada produk sehingga mempengaruhi kenampakan dari petis. Kenampakan yang homogen, padat namun 
elastis, dan berwarna coklat kehitaman merupakan ciri petis yang baik. Hal ini sesuai dengan pernyataan Astawan (2004) bahwa ciri-ciri petis yang baik yaitu berwarna cerah (tidak kusam) dan umumnya berwarna coklat kehitaman. Fajrita, et al., (2016) menyatakan bahwa nilai kenampakan tertinggi pada produk petis ikan yang memiliki kenampakan yang cerah, homogen, padat namun elastis.

\section{Tekstur}

Berdasarkan hasil penelitian untuk pengujian sensori atribut tekstur (Tabel 1) menunjukkan bahwa nilai rata-rata penilaian berkisar antara 3,50-3,79 (suka). Salah satu ciri petis yang baik adalah kental tapi sedikit encer dari margarin (Sari dan Kusnandi, 2015). Tekstur petis ikan layang yang dihasilkan lebih dipengaruhi oleh faktor suhu dan lama pemanasan. Proses pemanasan yang terjadi dengan memekatkan gula pada air rebusan ikan layang mengakibatkan terjadinya proses penguapan. Pada waktu air menguap kemudian larutan menjadi lebih pekat dan akan meningkatkan viskositas larutan dengan tajam. Jika lama pemanasan berlebih dan peningkatan viskositas terlalu tinggi, cairan menjadi terlalu liat dan lebih sulit dipanaskan, mengakibatkan sebaran suhu yang tidak seragam dalam bahan pangan. Bercak panas dan hangus pada bahan pangan dapat terjadi dan mengakibatkan penurunan mutu yang mencolok (Harris et al., 1975).

\section{Rasa}

Berdasarkan (Tabel 1), nilai rata-rata rasa petis ikan layang berkisar antara 3,40-3,79 (agak suka-suka). Adanya pembentukan rasa enak adalah hasil degradasi dari asam amino alfa diubah menjadi aldehid dengan atom karbon yang berkurang satu. Rasa manis ditimbulkan oleh senyawa organik alifatik yang mengandung gugus $\mathrm{OH}$ seperti alkohol, beberapa asam amino, aldehida dan gliserol. Sumber rasa manis terutama berasal dari gula atau sukrosa (Sudarmadji, 1982). Astawan (2004) menjelaskan rasa gurih pada petis daging berasal dari dua komponan utama, yaitu dari peptida dan asam amino yang terdapat pada kaldu daging.

\section{Nilai pH dan TVB Petis lkan Layang}

Hasil analisis nilai pH dan TVB petis ikan layang dengan penambahan jenis asam yang berbeda disajikan pada Tabel 3.

Tabel 3. Nilai pH dan TVB petis ikan layang

\begin{tabular}{lll}
\hline Jenis asam $(0,4 \%)$ & $\mathrm{pH}$ & TVB $(\mathrm{mgN} / 100 \mathrm{~g})$ \\
\hline Jeruk nipis & 5.13 & 7,408 \\
Asam cuka & 4.05 & 8,062 \\
Asam sunti & 4.86 & 9,587 \\
\hline
\end{tabular}

Uji pH

Uji pH berfungsi untuk melihat derajat keasaman suatu bahan. Berdasarkan (Tabel 3) dilihat bahwa nilai $\mathrm{pH}$ petis ikan layang berkisar antara 4,05 - 5,13 nilai pH pada penelitian ini dikatakan normal. Nilai pH petis dengan penambahan asam sunti lebih rendah dibandingkan dengan petis dengan penambahan jeruk nipis. Hal ini dikarenakan belimbing wuluh sebgai bahan baku asam sunti mengandung lebih banyak senyawa kimia penghasil asam diantaranya asam format, asam askorbat, dan asam sitrat (Hutajulu et al., 2009). Dibandingkan dengan buah jeruk nipis yang diukur pada 100 gram mengandung sebanyak 49 gram asam askorbat (Dewi, 2012). Penelitian Danitasari (2010) menyatakan bahwa nilai rata-rata $\mathrm{pH}$ pada air rebusan ikan Tongkol sebesar 5,25 dan pada petis ikan Tongkol sebesar 5,32 . Petis termasuk pangan berasam rendah yaitu pangan dengan nilai $\mathrm{pH} \mathrm{4,6}$ atau lebih. Air rebusan ikan Tongkol memiliki pH asam akibat pengaruh fisiologis daging ikan Tongkol yang digunakan dalam proses pemindangan. Penambahan asam jeruk limau dapat menurunkan $\mathrm{pH}$ petis ikan Tongkol, (Mancini et al., 2007) semakin besar konsentrasi asam jeruk limau yang ditambahkan dengan kandungan asam sitratnya maka semakin rendah $\mathrm{pH}$. Akan tetapi dengan banyaknya jumlah gula yang ditambahkan dimana gula bersifat basa dapat meningkatkan kembali $\mathrm{pH}$ petis ikan Tongkol. Sehingga perubahan nilai pH yang terjadi dalam jumlah yang kecil, dan produk termasuk dalam golongan pangan berasam rendah. 


\section{Uji TVB}

Uji TVB berfungsi untuk mengetahui tingkat kesegaran ikan dan sebagai batasan yang layak untuk dikonsumsi. TVB biasa digunakan sebagai salah satu parameter tingkat penurunan mutu produk-produk perikanan, Selama berlangsungnya proses penurunan mutu ikan, protein diuraikan oleh bakteri-bakteri pembusuk menjadi senyawa-senyawa nitrogen yang lebih sederhana seperti trimethylamin, dimethylamin, dan ammonia serta senyawa-senyawa berbau lainnya seperti asam-asam keton yang selajutnya akan berubah menjadi aldehid dan keton (Zaitsev, 1969). Berdasarkan hasil penelitian ikan layang yang digunakan pada pembuatan petis ini layak konsumsi karena pada tiap perlakuan memiliki nilai dibawah 10 $\mathrm{mgN} / 100 \mathrm{~g}$ yaitu dengan nilai berkisar antara 7,408 -
9,587. Menurut (Farber, 1965) tingkatan ikan sangat segar (TVB $<10 \mathrm{mgN} / 100 \mathrm{~g})$, ikan segar $(10 \leq \mathrm{TVB} \leq 20$ $\mathrm{mgN} / 100 \mathrm{~g}$ ), ikan masih layak konsumsi ( $20 \leq \mathrm{TVB} \leq 30$ $\mathrm{mgN} / 100 \mathrm{~g}$ ), ikan tidak layak konsumsi ( $>30 \mathrm{mgN} / 100$ g). Tidak terjadinya kenaikan nilai TVB pada petis ikan layang ini dikarenakan tidak terjadi reduksi senyawa trimetilamin oksida (TMAO) dan senyawa non protein nitrogen lainnya menjadi TMA oleh bakteri dan enzim (llyas, 1983).

\section{KESIMPULAN}

Perbedaan pemberian jenis asam pada petis ikan layang berpengaruh nyata terhadap nilai hedonik rasa, dimana petis dengan penambahan jenis asam jeruk nipis sebanyak $0,4 \%$ lebih digemari dengan nilai $\mathrm{pH} 5,13$ dan nilai TVB 7,408 mgN/100g.

\section{DAFTAR PUSTAKA}

Afrianto, E, Liviawaty, E. 1989. Pengawetan dan Pengolahan Ikan. Kasinisius. Yogyakarta

Astawan, M. 2004. Petis, Si Hitam Lezat Bergizi. dikutip dari: http://cyberman.cbn.net.id/cbprt//cybermed/de tail.aspx? $\mathrm{x}=$ nutrition $\& \mathrm{y}=$ cybermed $\% 7 \mathrm{C} 0 \% 7 \mathrm{C}$ $0 \% 7 \mathrm{C} 6 \% 7 \mathrm{C} 320$. Diakses pada tanggal 10 Oktober 2019 pukul 15:30.

Cahya, G. Baehaki, A. Nopianti, R. 2014. Karakteris Tik Dan Aktivitas Antioksidan Petis Air Rebusan Kepala Gabus (Channa Striata) Dan Tenggiri (Scomberomorus Commersoni) Dengan Perbedaan Konsentras I Gula Kelapa. Volume III, Nomor 01.

Danitasari, SM. 2010. Karakterisasi Petis Ikan Dari Limbah Cairan Hasil Perebusan Ikan Tongkol (Euthynnus Affinis). (Skripsi). Institut Pertanian Bogor. Bogor

Heruwati, E.S.1986. Keamanan Produk Periakanan Sebelum Dan Selama Pengolahan Serta Selama Penyimpanan Dan Distribusi. dalam Prosiding Seminar Keamanan Pangan dalam Pengolahan dan Penyajian. 1-3 September 1986. Pusat Antar Universitas Pangan dan Gizi UGM. Yogyakarta.

Hernawati, Jawiana, Saokani dan Heriansah. 2017. Pengaruh Penambahan Garam Terhadap Karakteristik Petis Berbahan Limbah Padat
Ikan Tongkol (Euthynnus Affinis) [Skripsi] Mahasiswa Program Studi THP STITEK Balik Diwa Makassar Volume 8Irfan, M. (2013) Respon Bawang Merah (Allium Ascalonicum L) Terhadap Zat Pengatur Tumbuh Dan Unsur Hara," Jurnal Agroteknologi, 3(2).

llyas, S. 1983. Teknologi Refrigerasi Hasil Perikanan Jilid I. Teknik Pendinginana Ikan. Peripurna. Jakarata.

Murniati, D. 2007. Pemanfaatan Kitosan Sebagai Koagulan Untuk Memperoleh Kembali Protein Yang Dihasilkan Dari Limbah Cair Industri Pemindangan Ikan. Tesis. Sekolah Pasca Sarjana.

Nursanto, I., 2004, Pembuatan Minuman Sebagai Usaha Diversifikasi Rumput Lauteucheuma Cottoni, Skripsi Fakultas Perikanan Dan IImu Kelautan Institut Pertanian Bogor, Bogor.

[PPS] Pelabuhan Perikanan Samudera Kendari. 2011. Laporan Statistik Tahunan Pelabuhan Perikanan Samudera Kendari. Kendari: Kementrian Kelautan dan Perikanan (KKP)Direktorat Jenderal Perikanan Tangkap.

Oktavia, D. A. dkk. 2012. Pengolahan Limbah Cair Perikanan Menggunakan Konsorsium Mikroba Indigenous Proteolitik dan Lipolitik. Agrointek, 6(2): 65- 71.

Poernomo D. Suseno. H. S. Wijatmoko A. 2004. 
Pemanfaatan Asam Cuka, Jeruk Nipis (Citrus Aurantifolia) danBelimbing Wuluh (Averrhoa bilimbi) untuk Mengurangi Bau AmisPetis Ikan Layang (Decapterus spp.)

Purnomo Eddy. (2002)," Teknologi Tepat Guna : Penyamakan Kulit Ikan. Paril", Kanisius , Jogjakarta.

Vanirawan B. 2010. Artikel : Pembuatan Asam Cuka. http://bagasvanirawan.wordpress.com/. [diakses tanggal 27 Februari 2012].

Waryanti, A., Sudarno., E. Sutrisno. 2013. Studi Pengaruh Penambahan Sabut Kelapa pada
Pembuatan Pupuk Cair dari Limbah Air Cucian Ikan terhadap Kualitas Unsur Hara Makro (CNPK).

Wijatmoko, A. 2004. Pemanfaatan Asam-asam Organik (Asam Cuka, Jeruk Nipis (Citrus auratifolia) dan Belimbing Wuluh (Avverhoa blimbi) Untuk Mengurangi Bau Amis Petis Ikan Ikan Layang (Decaptterus sp). Skripsi. Bogor: Institut Pertanian Bogor.

Zaitsev, V., Kizervefler, L.Luganov, T. Makarov, L. Minder, and V. Podseralov, 1969. Fish Curing and Processing. Mir Publising, Moscow. 